\title{
VERTICAL ZONATION OF THE SPELEOGENETIC SPACE
}

\section{VERTIKALNA CONACIJA SPELEOGENETSKEGA PROSTORA}

\author{
FRANCE ŠUŠTERŠIČ ${ }^{1}$
}

\footnotetext{
${ }^{1}$ University of Ljubljana, Department of Geology, Aškerčeva 12, SI-1000 LJUBLJANA, SLOVENIA, E-mail: <france.sustersic@ntfgeo.uni-lj.si>
} 


\section{France Šušteršič: Vertikalna conacija speleogenetskega prostora}

Namen članka je pokazati, da ne obstoji samo prostorska domena, kjer podzemske kraške oblike sistematično prehajajo v nekaj drugega in izginjajo, ampak tudi, da lahko na osnovi tega znanja kraške votline trdneje vpnemo v logični okvir geospeleološkega prostora/časa. Prava kraška jama je vsaka podzemska kraška oblika, ki je nastala kot posledica odnašanja mase v raztopini, ob pogoju, da je trajekrotorija vodnega toka, ki jo je izoblikoval, tekla skozi (jamo), ne glede na njene izmere. Speleogenetski prostor definiramo v tem kontekstu kot tisti del Zemljine skorje, v katerem lahko nastajajo kraške jame. Tedaj je zakrasela kamninska masa aktiviran speleogenetski prostor. Zaradi denudacije in zniževanja gladine podtalnice se zdi, da posamezna jama po speleogentskem prostoru potuje navzgor, dokler ne doseže površja. Kraška denudacija deluje navpično in prizadeva matično kamnino znotraj cele vrhnje plasti, isto pa seveda velja za vse oblike znotraj kamnine. Zato lahko uvedemo pojem speleotanske cone. Znotraj nje je napadena vsa kamnina, na vsaki možni površini in končna posledica je njeno popolno izničenje. Slično razgradnjo bodo v stiku z agresivno vodo doživele vse strukture v kamnini, ne glede na izvor. Glede na značilno oblikovanje/razgrajevanje kraških votlin lahko znotraj spelogenetskega prostora definiramo tri speleoformativne/de-formativne cone.

Ključne besede: speleogenetski prostor, conacija krasa, denudacija, speleogeneza, jamski sistem, brezstropa jama.

\section{Abstract}

UDC: 551.44:551.311.24

\section{France Šušteršič: Vertical zonation of the speleogenetic space}

The point of this paper is to demonstrate that not only the spatial domain where underground karst phenomena are being systematically transformed exist but also that this knowledge makes the role of caves within the geospeleological space/time more consistent. A true cave is any underground karst feature resulting from mass removal, regardless of its dimensions provided that the trajectory of the formative water passes through the cave and that the mass is removed in liquid phase (solution). Speleogenetic space is defined as that portion of the Earth's crust within which karst caverns may be formed. Thus, a karstified rock mass is defined as activated speleogenetic space. Due to the effects of denudation and watertable lowering, as the time passes a single cave seems to move upwards through speleogentic space, until it reaches the surface. The denudational logic of the karst surface is vertical, and the rock suffers disintegration throughout the thickness of its outermost layers. The same argument applies also to in-rock features. Consequently, the idea of the speleothanatic zone is introduced. Within it all of the rock is attacked, on any possible surface, and the final result is its complete annihilation. It may be expected that all structures, of any origin, that expose the rock surface to contact with aggressive water, will evolve via some "speleothanatic" progression. It is demonstrated that three vertical zones of specific formative/de-formative processes exist within speleogenetic space.

Key words: speleogenetic space, zonation of the karst, denudation, speleogenesis, cave system, unroofed cave. 


\section{INTRODUCTION}

Recognition of "roofless caves" (A. Mihevc, 1996, 1998) and more general, "surface caving" (F. Šušteršič, 1998-b), did not bring about a discovery of many a previously unknown karst features. Rather than - though some of them really appear to be unknown before - it revealed that features, previously supposed to be exceptions or curiosities, take regular part in the karst surface and within the layer close to it. The point of this paper is to demonstrate that not only the spatial domain where underground karst phenomena are being systematically transformed exist but also that this knowledge makes the role of caves wihin the geospeleological space/time more consistent.

After the proper word has been said, it is easy to trace back if anything similar had apeared once upon a time before. However, it appears to be self-understood that, in the karst, steady denudational activity "brings" endokarstic phenomena to the surface. In fact, many authors mention isolated examples of various endokarstic phenomena appearing at the surface and most of schoolbooks list "denuded underground phenomena" explicitly among the standard inventory of the surface karst features, without entring into details. All these lack an idea that such phenomena might be regularly interrelated, and that there exists well defined spatial domain, with equally well defined rules of cave (trans)formation.

In Slovenia, seemingly P. Habič (1963) was the first to become vaguely aware that all such phenomena might be interrelated. In his paper, dealing with the caves between the Planinsko polje and Ljubljanica springs, he mentioned four fundamental groups. He says (o.c, 4): “... Less known are the origin and function of shorter caverns named "dens" (slov. = brlog) and "little cellars" (slov. = kevderc), as termed by the local people. These caves do not differ a lot from the ones of the fourth group..."2, and further on (o.c., 7): “... The fourth group encompasses small - vertical or oblique - narrows, overhangs and excavations between the limestone strata within perpendicular walls or in the slope..."2.

That cave (trans)formation is somehow connected by the proximity of the surface, was indicated by F. Šušterič and M. Puc (1970, 262). When describing a small cave north of Planinsko polje, they observed that: “...Similarly to Tatova jam the (mentioned, note F. Š.) cave is somehow superficial object of unclear origin..." .

The recognition of a special domain within the karst appears to be evident with P. Habič (1976), when discussing the caves in the Ljubljanica river basin. He (o.c, 19) wrote: “... three more expressive levels ... have been stated. The lowest level is now active, the medium the most extensive and generally dry, the highest one is preserved only in shorter cave passages, being much transformed by breakdowns." It is noted that this is just a generalisation. The model can not be applied completely to pure "fluvially terraced" underground karst, because a variety of "levels" are found in different caves. In any case, the "highest" level does not fit the fluvial logical pattern at all, as it becomes clear from its context that it is surface, not elevation dependent.

Since then, no progress has been achieved until A. Mihevc, together with his co-workers ${ }^{3}$ begun systematically to present various aspects of appearance of denuded underground karst phenomena on the surface. The Authors contribution in this field is summarised in F. Šušteršič, 1998, based on very detailed surface mapping of a denuded deep phreatic system.

\footnotetext{
${ }^{2}$ Translation by F. Šušteršič.

${ }^{3} 1995$ - 1999, see References!
} 


\section{THE SPELEOGENTIC SPACE}

From the point of view of the Pure Karst Model (F. Šušteršič, 1982, 1996-a) a true cave is any underground karst feature resulting from mass removal (F. Šušteršič, 1979), regardless of its dimensions. The crucial condition is that the trajectory of the formative water passes through the cave and that the mass is removed in liquid phase (solution) (F. Šušteršič, 1984, 61) The infinitesimally small element of a cave that still holds its basic properties is defined as a ring of phase boundaries ${ }^{4}$, perpendicular to the trajectory direction. Such infinitesimally small element is termed Differential Speleogene ${ }^{5}$ Element (DSE), (o.c., p. 65). Consequently, a cave channel is a continuous string of DSEs. The length (along the trajectory) of a single DSE is negligible, though its diameter may be as large as the widest cavern.

Speleogenetic space (F. Šušteršič, 1991, pp. 82 - 86) is defined as that portion of the Earth's crust within which karst caverns may be formed. At a certain stage of its activation, caves appear within the speleogenetic space. Thus, underground karstification (or speleogensis) is defined as the process of establishing continuous DSE strings (F. Šušteršič, 1984), and a karstified rock mass is defined as activated speleogenetic space ${ }^{6}$ (F. Šušteršič, 1991). In these terms vadose intergranular dissolution of carbonate during diagenesis is not karstification, unless it brings about the formation of distinct channels. (Fig. 1) Thus, geometry is as important as the chemistry and the physics of the process.

If more detailed considerations (and some questions of semantics) are ignored, activated speleogentic space can be divided broadly into two zones. The (water) saturated (phreatic) zone below, and the (water) unsaturated (aerated ${ }^{7}$ or vadose ${ }^{7}$ ) zone above. Though this definition is basically hydrogeological, it fits perfectly within common speleological situations, because, in general, "horizontal" and "vertical" caves are the specific products of hydrogeological conditions intrinsic to the two zones ${ }^{8}$. Though in some cases the voids formed in a particular zone might resemble those formed in the other, the differences are generally clear-cut, and further discussion is not needed. Perhaps it should be added that, in the case of straightforward development, the initial structures of caverns imposed under saturated conditions are obviously geological, whereas the initial structures of voids in the unsaturated zone may be geological or speleological (inherited and modified from those imposed in the saturated zone).

Due to the effects of denudation and watertable lowering (generally reflecting uplift), as the time passes, a single cave seems to move upwards through speleogentic space, until it reaches the surface. The denudational logic of the karst surface is vertical, not horizontal (F. Šušteršič, 1996-a) and the processes operate perpendicularly, extending their activity to a certain specific depth (I. Gams, 1997). Consequently, instead of suffering lateral erosion / accumulation / final removal of the mass only at the expossed upper surface, the rock suffers disintegration throughout the thickness

\footnotetext{
${ }^{4}$ In the sense of R. L. Curl (1964).

${ }^{5}$ Meant as a synonym for cave $(G r .: \sigma \pi \eta \lambda \alpha \mathrm{lov}=$ cave, $\gamma \varepsilon v v \alpha o=$ to generate $)$. Because this wider sense of the word speleogene is not common in English, the term is avoided in the present text.

${ }^{6}$ In this context "activation" means the beginning of karstic activity within the speleogenetic space.

${ }^{7}$ The expression used depends upon the researcher's academic bacground.

${ }^{8}$ Due to perfect overlapping, new terms will not be introduced.
} 


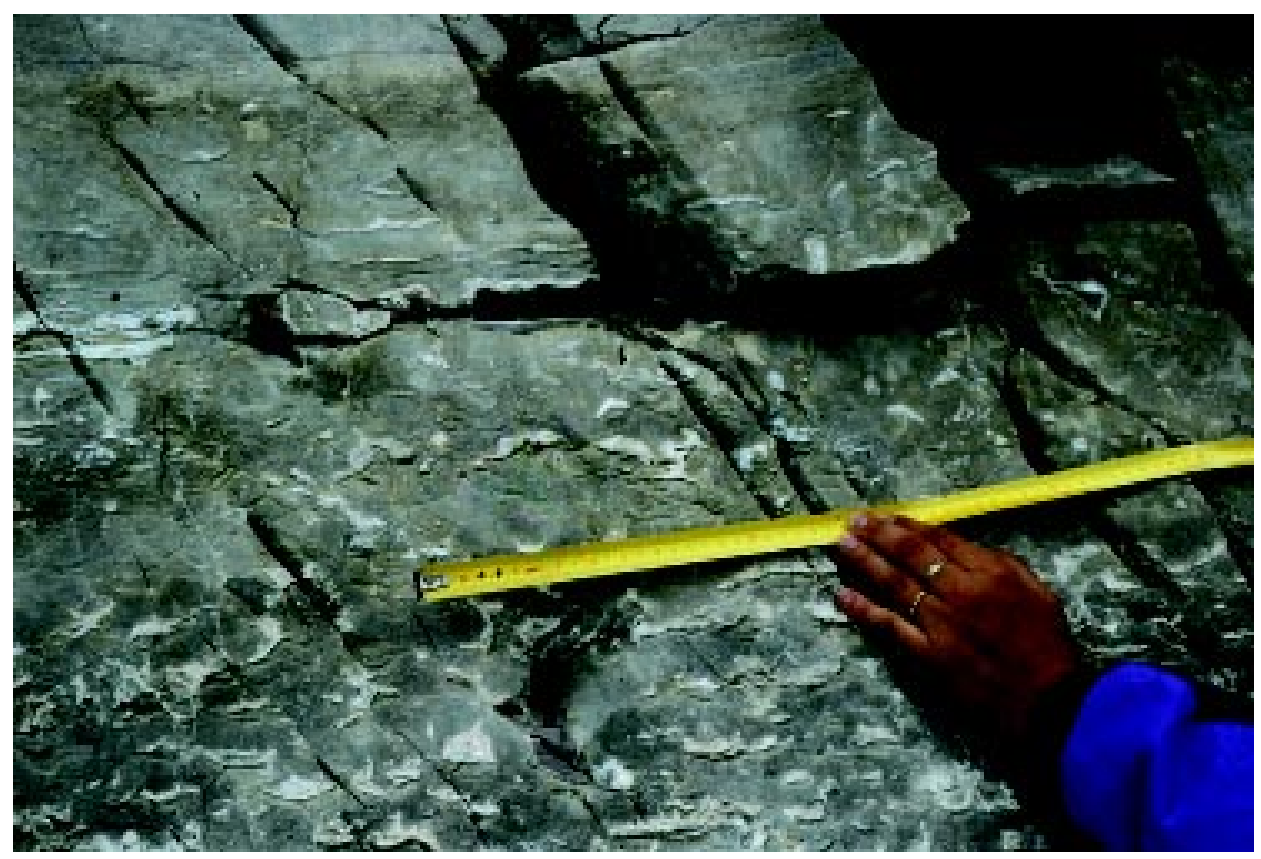

Fig. 1: Palaeokarst on Mt. Batognica (Mt. Krn massif, Slovenia). Across most of the picture white (calcite crystal) bands surround infillings of parent rock type material within chaotically arranged cavities (mostly reworked mollusc shells). These cavities were formed (and refilled) during diagenesis, possibly under haloclinal conditions. Water must have moved through the cavities, but details of its course are undetectable and these phenomena are not karstic sensu stricto. Reddish areas elsewhere in the picture are small phreatic tubes filled with red clay. Though these features are only slightly younger than those described above, channel geometry and movement direction are both evident. Both of these infilled cavity types are good examples of palaeokarstification, but only the latter features are karstic sensu stricto.

Sl. 1: Paleokras na Batognici (Krnsko pogorje). Beli pasovi kalcitnih kristalov na večini slike obrobljajo polnilo v kaotično razmetanih votlinicah (pretežno spremenjenih lupinah mehkužcev), ki se na pogled ne razlikuje od matične kamnine. Votlinice so nastale in bile zapolnjene v času diageneze, verjeno v haloklinalnih pogojih. Prežemala jih je voda, toda načina pretakanja se ne da ugotoviti. Zato te votlinice sensu stricto niso kraške. Števično zelo podrejena rdečkasta območja so majhni freatični kanali, zapolnjeni z jerovico. Četudi so le za malenkost mlajši od "kaotičnih" votlinic, sta geometrija kanalov in potek trajektorij toka jasno razvidna. Oba tipa zapolnjenih votlin sta dobra primera paleozakrasevanja, vendar so v pravem smislu besede kraške le votlinice drugega tipa. 
of its outermost layers. The same argument applies also to in-rock features. That is, caves, inherited from the time when the mass in question formed part of the lower two zones ${ }^{9}$.

Though belonging vaguely to the (water) unsaturated zone, the uppermost layer has a distinct hydrogeologcal regime and is usually termed the epikarstic zone, or (due to its contact with the soil cover) the subcutaneous zone. However, this terminology says nothing about the caves so, for current purposes, the term speleothanatic ${ }^{10}$ zone is introduced. Within the speleothanatic zone all of the rock is attacked, on any possible surface, and the final result is its complete annihilation. It may be expected that all structures, of any origin, that expose the rock surface to contact with aggressive water, will evolve via some "speleothanatic" progression, which should be recognizable for some time before total decay is achieved. There are no obvious reasons to expect any new DSE strings to form within the speleothanatic zone.

\section{The cave history within the speleogenetic space/time}

Thus, from the viewpoint of cave (de-)formation (ie. disintegration), the statement that a definable zone exists where they are just de-formed (rather than formed), is tenable and logically supported. It is hard to believe that Habič (1976) progressed so far and so clearly, by reasoning along these lines. Nevertheless, he opened the way to allow generalisation of his statements about three levels within the following zonal framework:

Table 1.1:

\begin{tabular}{|c|c|c|c|}
\hline $\begin{array}{c}\text { spatial categories } \\
\text { of cave transfrormation }\end{array}$ & Habič's terminology & $\begin{array}{l}\text { speleological } \\
\text { process }^{11}\end{array}$ & description \\
\hline $\begin{array}{c}\text { speleodestructive } \\
\text { domain }\end{array}$ & highest level & $\begin{array}{l}\text { DSEs are being } \\
\text { destroyed }\end{array}$ & zone of disintegration \\
\hline $\begin{array}{l}\text { speleoformative } \\
\text { domain }\end{array}$ & $\begin{array}{l}\text { medium level } \\
\text { lowest level }\end{array}$ & $\begin{array}{l}\text { formation of vertically }{ }^{12} \\
\text { oriented DSEs } \\
\text { formation of horizontally }{ }^{12} \\
\text { oriented DSEs }\end{array}$ & $\begin{array}{c}\text { formation of } \\
\text { "vertical" caves } \\
\text { formation of "horizontal" } \\
\text { caves }\end{array}$ \\
\hline
\end{tabular}

In the other words, three vertical zones of specific formative/de-formative processes exist within speleogenetic space. The lower two may be merged in the speleoformative domain which means that speleogenetic space itself basicaly consists of two domains (layers), one "constructive", the other "destructive". The latter expressions are placed within the quotation marks because the speleoformative process is destructive overall, when considered from the positive mass and human viewpoints.

\footnotetext{
${ }_{9}^{9}$ Thus, the surface features of the size order 1 - 10 m are denuded caves, reworked geological structures and, possibly, forms inherited from previous nonkarsic conditions or prouducts of cosmopolitan (in the sense of F. Šušteršič, 1996-a) processes.

${ }^{10}$ Gr.: Janatos $=$ death.

${ }^{11}$ The term meant as analogy of "geomorphic process".

${ }^{12}$ Meant in the sense that this component is essential to the process.
} 
If apparently well-known facts about the karst are arranged according to this logic, Table 1.1 may be expanded to give:

Table 1.2:

\begin{tabular}{|c|c|c|c|c|}
\hline $\begin{array}{c}\text { Habič's }{ }^{13} \\
\text { terminology }\end{array}$ & $\begin{array}{c}\text { Hydrological } \\
\text { function }\end{array}$ & $\begin{array}{c}\text { Adaptation of } \\
\text { geological structures }\end{array}$ & $\begin{array}{c}\text { Processes } \\
\text { characteristics }\end{array}$ & $\begin{array}{c}\text { Dominant karst } \\
\text { activity }\end{array}$ \\
\hline highest level & epikarst $^{14}$ & $\begin{array}{c}\text { total activation of } \\
\text { all transmissive } \\
\text { structures }\end{array}$ & bioactivity & $\begin{array}{c}\text { total decay } \\
\text { of the rock }\end{array}$ \\
\hline medium level & $\begin{array}{c}\text { water unsaturated } \\
\text { zone }\end{array}$ & $\begin{array}{c}\text { vertical } \\
\text { breakthroughs }\end{array}$ & $\begin{array}{c}\text { no feedback } \\
\text { (upwards) effect }\end{array}$ & $\begin{array}{c}\text { formation of avens } \\
\text { and dome pits }\end{array}$ \\
\hline lowest level & $\begin{array}{c}\text { water saturated } \\
\text { zone }\end{array}$ & $\begin{array}{c}\text { selective activation } \\
\text { of geological } \\
\text { structures }\end{array}$ & $\begin{array}{c}\text { system of } \\
\text { interconnected } \\
\text { vessels }\end{array}$ & $\begin{array}{c}\text { formation of } \\
\text { bedding-plane } \\
\text { channels and } \\
\text { phreatic jumps }\end{array}$ \\
\hline
\end{tabular}

To pursue the chain to its logical conclusion, a fourth zone would need to be included, below the (water) saturated one, this being the zone of as yet unactivated speleogenetic space. Because its properties lie completely outside this discussion (put relate to question of cave origin), it is not investigated further here.

Through the time, a cave seems to move through the speleoforming domain and into the speleothanatic zone (destructive domain). Putting this knowledge into a wider geo-speleological framework, and considering some other previously overlooked processes, the following speleogenetic scheme can be derived (Table 2, next page):

Many details of this table are worthy of further discussion (covered partly by footnotes) but only the zone of decay, i.e. speleothanatic zone is of direct interest here.

Rock disintegration leads not only to the destruction of the cave structures, but it has other effects upon any exposed rocky surface. Commonly, the penetration of soil (and relateded bioactivity) into fractures leads to the formation of specific (negative) rocky forms, generally referred to as pockets. The process is superficial, not karstic, however, because water trajectories do not pass through phase boundary "rings". Instead they run along generally smoothly-polished but irregularly corrugated walls, many of which are laterally open.

Additionally, some primary geological structures retain their fundamental geometry during this type of weathering, to such an extent that the term "pockets" may not sensibly be attributed to them. The boundary between the latter and the former is, however, very arbitrary, athough the basic forms may readily be distinguished. In absolute terms, pockets and "weathered geological structures" outnumber decayed caves, and local factors (fracture density, bed thickness, rock mineralogy, late Quaternary history etc.) will influence which of the two will dominate locally.

\footnotetext{
${ }^{13}$ Perhaps not used here in the exact sense of its original meaning, but applied loosely in this way is is very useful because it is absolute neutral.

${ }^{14}$ In the sense of P. Williams (1983).

${ }^{15}$ In the sense of any discontinuity within the rock, of any origin, capable of boosting the penetration of water.
} 
Table 2:

\begin{tabular}{|c|c|c|c|}
\hline \multirow{2}{*}{$\begin{array}{c}\text { Speleological } \\
\text { process }\end{array}$} & \multirow{2}{*}{\multicolumn{2}{|c|}{$\begin{array}{c}\text { Processes in the speleogenetic } \\
\text { space } \\
\text { (Evolution of DSE-es) }\end{array}$}} & Process in the rock \\
\hline & & & \multirow{2}{*}{ DIAGENESIS } \\
\hline \multirow[t]{4}{*}{ 1. Speleogenesis } & 1.1 & Inception & \\
\hline & 1.2 & Gestation & \multirow{7}{*}{ REPLACEMENT $^{18}$} \\
\hline & 1.3 & Widening & \\
\hline & 1.4 & Stagnation $^{17}$ & \\
\hline \multirow[t]{3}{*}{ 2. Transformation } & 2.1 & Collapse & \\
\hline & 2.2 & Perforation $^{19}$ & \\
\hline & 2.3 & Infilling & \\
\hline \multirow[t]{3}{*}{ 3. Decay } & 3.1 & Disintegration of the roof & \\
\hline & 3.2 & Disintegration of the walls & \\
\hline & 3.3 & Transformation of infilling & PEDOGENESIS ${ }^{20}$ \\
\hline
\end{tabular}

In the speleoformative domain DSEs tend to be enlarged. Where they coalesce the phase boundary "rings" merge but keep their full identity. Even in the spelothanatic zone some previously generated DSEs may continue to expand if their axis orientations approximate roughly to the vertical (downward) direction. However, this is not inevitable and even where it does occur the logic of the "throughflow" is lost. Openings within the rock mass will enlarge and merge in any possible way, generally reflecting the disintegration characteristics of the parent rock and the availability of fresh,

\footnotetext{
${ }^{16}$ The succession is logical, not inevitably temporal. Many omissions and short-cuts are possible and more realistic picture of relations might be obtained only by transition matrix.

${ }^{17}$ In the sense that the paragenetic threshold has been achieved.

${ }^{18}$ In a way formation of caves may be compared to metasomatism, as the guiding structures and the process chemistry are to some extent analogous. However, during metsomatism solid phase (rock) is replaced by another solid, usually ore mineral, and some information about the previous state, and the process itself, remains "frozen" in the new solid. During speleogenesis, the rock is replaced by fluid, primarily water, and later, possibly, by air. In this case, the informational chain is irreparably broken. Later replacements by various speleothems (used in the wider sense of word: $(G r .: \sigma \pi \eta \lambda \alpha \iota 0 v=$ cave, $\tau \imath \vartheta \eta \mu \iota=$ to place $)$ will accumulate information about infilling and other mass-movement processes, but can never provide information about what happened before. These, purely theoretical, aspects are commonly forgotten, and the rudimentary similarity between metasomatism and speleogenesis is overlooked.

${ }^{19}$ The DSE was defined as ring of phase boundaries, formed in phreatic conditions. When being transferred into the (water) unsaturated zone, the rock may be exposed to vertical shaft formation. If subsequently formed vertical shaft tears-open the DSEs where in contact, the result is what cavers describe as an aven.

${ }^{20}$ In the case that only carbonate minerals are present, pedogenesis may be reduced or completely omitted.
} 
aggressive, percolation water. In this way all penetrable discontinuities in the rock expand and finally coalesce, regardless of their origin, and after some time they become indistinguishable. If negative masses have been replaced by different infillings before this merging, their identity can commonly be reconstructed though generally their actual geometry remains obscure.

\section{SOME DETAILS}

It is pertinent the question why the term "speleothanatic zone" is introduced, and used in preference to the better known terms epikarstic or subcutaneous zone. The reason is not just academic.

D. Ford and P. Williams (1991, p. 123), describe the former: "... epikarst" ${ }^{11}$, the upper part of the percolation zone”. A. Klimchouk (1995, p. 45, Table 1) provides a clearly tabulated synthesis of the various ways that this expression has been used. From his table it is evident that the term appears only once purely in the context of morphogenetic processes (which is closer to the context of the present paper). In all other cases it is bound, at least partly, to the hydrological aspects. Klimchouk himself (o.c.) uses this term in the the context of its mixed meaning, hardly mentioning the possibility that epikarstic zone is the general focus for cave disintegration. Thus, the epikarstic zone is widely regarded just as being a sort of temporary (water) reservoir fo the unsaturated zone.

In the case of total decay of caves, it is not the impeded vertical percolation, but possibility for planar dissolution of rock, that is crucial. Thus, the epikarstic zone may extend below the lower limit of the spelothanatic zone, if the decrease of water aggressivness is essentially faster than its gathering into well-defined trickles. The alternative is that water retains significant aggressiveness after its movement has switched from diffuse seepage to (small) channel flow. Both options appear to be possible, and perhaps bring about the development of different fundamental types of solution doline (F. Šušteršič, 1994).

It appears that bedrock phenomena in the epikarstic zone have not yet been studied with an emphasis on this point of view, though some of A. Klimchouk's (o.c.) work is a is partial exception. However, the spelothanatic zone concept relies upon only one of formerly listed factors, i.e. diffuse water aggressiveness. Until the effects of laterally moving epikarstic water upon the rock are known in sufficient detail, the relationship between the epikarstic and spelothanatic zones remains unclear.

The other possible alternative term is the subcutaneous zone. D. Ford and P. Williams (1989, p. 162) say: “... subcutaneous ${ }^{21}$ zone which lies immediately beneath the soil above the main mass of largely unweathered rock." I. Gams (1971) provides an exhaustive survey of subcutaneous forms (terming them subsoil karst forms) and processes. The stress is placed upon specific forms appearing at the bedrock surface, though the initial (geological) structures are not ignored. The possible existence and transformation of cave structures (except for vertical shafts) falls outside his consideration. Nevertheless, though it is evidently understood as being a sort of karst surface geomorphic environment, its spatial position and the processes that operate within the subcutaneous zone make the term closer in meaning to the idea of the spelothanatic zone than to common view of the epikarstic zone.

\footnotetext{
${ }^{21}$ Italics by F. Šušteršič.
} 
Though touched upon previously, the question of what comprises the lower boundary of of the speleothanatic zone remains to be answered. Logically, the boundary corresponds to the lowest limit of active DSE disintegration. This limit may be set in response to various influences, such as lowering of the corrosion potential, concentration of flow into channels, or the diffuse downflow being too fast to allow sufficient reaction time. In recent works, I. Gams $(1997,1998)$ refers to the "corrosional front". It appears that this could equate reasonably well with the lower limit of the speleothanatic zone. Unfortunately, the Author has been unable to trace the original definition of the expression.

Superimposed pocket formation, together with soil penetration (and intimately related bioactivity) appear to be visible and definitive consequences of speleothanatic conditions, offering a pointer to their occurence in any given area. More positively, pocket formation is intimately related to the disintegration of roofs and walls, regardless of whether the caves were empty or had been subsequently filled. Such relationships are well displayed in many road cuts and quarries. As with subcutaneous forms in general, smooth walls are charcteristic of pockets, and they are explained as being produced by the action of diffuse water, percolating through the soil and down fractures.

Fractures that are not obviously enlarged, not even penetrated by soil, but are simply more transmissive, appear to be more frequent near the surface. This is usually explained as reflecting unloading or relaxation following uplif. The potential roles of these two agents cannot be ignored. However, the list of local effects that do not rely directly upon rock mechanics has not yet been exhausted. For example, I. Gams (1971) has discussed the influence of permafrost. Shrinkage and swelling due to alternate drying and wetting of some clay minerals may result in very similar effects. In such cases, the increase in volume of rock plus "swollen" soil might provoke minimal arching, which could be followed by soil penetration into bedding plane partings and any predominantly horizontally orientated fractures. Field evidence of such effects is not uncommon, but generally the question of what was the generative process remains unanswered. Nevertheless, all of the effects listed are relatively easy observable and may serve as criteria for helping to determine of the lower boundary of the spelothanatic zone.

Another possible factor relating to cave disintegration must be taken into account. In Slovenia, in many larger caves ${ }^{22}$, the portions that are closer to the surface (less than about $60 \mathrm{~m}$ down) have evidently been affected more by slab spalling than those at greater deepth ${ }^{23}$. If this were due to corrosional loosening it would be a very clear criterion. However, the potential influence of the Pleistocene permafrost cannot be excluded (F. Šušteršič, 1996-b) and the question becomes even more complicated.

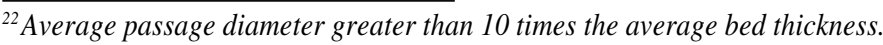

${ }^{23}$ This refers specifically to passages in less heavily deformed areas. Passages found in heavily fractured rock or in crush zones are more obviously affected by collapse, regardless of their position within she speleogenetic space, and their form is less closely tied to the relationship between passage dimensions and stratal thickness. The titles pf summaries are given to show English reades the contents of the original texts, which are considered intheir entirety in this paper.
} 


\section{REFERENCES}

Brenčič, M., 1993: Cave breakdown processes in caves, illustrated in the cave Košelevc on Ljubljanski vrh (in Slovene, English summary ${ }^{24}$ ). Naše jame, 35 (2), 25 - 31, Ljubljana.

Cucchi, F, A. Mihevc, F. Ferarese, U. Sauro, 1997: Classical Karst guide for the excursion. Meeting IUS 1997 in Italy, Postojna-Bologna, August 24-28. Suppl. Geogr. Fis. Dinam. Quat., III, T. 2 (1997), 167-180, Comitato glaciologico Italiano, Torino.

Curl, R.L., 1964: On the definition of a cave. NSS Bulletin 26 (1), 1 - 6.

Esteban, E.; F.C., Klappa, 1983: Subaerial exposure environments. In: Scholle, P.A.; D.G. Bebout; C.H. Moore, (eds.): Carbonate depositional environments. Mem. Am. Assoc. Petrol. Geol., 33, 1 - 57.

Ezhov, J.A.; G.P. Lysenin, 1986: The vertical hydrodynamic zonality of the Earth's crust (in Russian). Soviet Geology, 8, 111 - 120.

Ford, D.C; R.O. Ewers, 1978: The development of limestone cave systems in the dimensions of lenghth and breadth. Canadian journal of earth science 15, $1783-1798$.

Ford, D. C.; P.W., Williams, 1989: Karst geomorphology and hydrology. Unwin Hyman, 1 - 601, London.

Gams, I., 1963: Logarček (in Slovene, English summary). Acta carsologica 3, 1 - 84, Ljubljana.

Gams, I., 1966: Factors and dynamics of corrosion of the carbonatic rocks in the Dinaric and Alpine karst of Slovenia (in Slovene, English summary). Geografski vestnik 38, 11 - 68, Ljubljana.

Gams, I., 1971: Subsoil karst forms (in Slovene, English summary). Geografski vestnik 53, 27 - 45, Ljubljana.

Gams, I., 1997: Climatic and lithological influence on the cave depth development. Acta carsologica $26(2), 321-336$.

Gams. I., 1998: Chemical denudation as geomorphic process. Geografia fisica e dinamica qaternaria, 21, 19 -22, Torino.

Goudie, A., 1995: The changing Earth. Blackwell Publishers, 1 - 302, Oxford.

Habič, P.: 1963: Some results of the speleological explorations between Plannsko polje and Ljubljansko barje (in Slovene, English summary). Naše jame, 4, 3 - 8, Ljubljana.

Habič, P.: 1976: Geomorphologic and hydrographic characteristics. In: Gospodarič, R.; P. Habič, (eds.), Underground water tracing. Institute for Karst Research SAZU, 12 -27, Postojna.

Klimchouk, A., 1995: Karst morphogenesis in the epikarstic zone. Cave and karst science, 21 (2), $45-50$.

Mihevc, A., 1995: The Morphology of shafts on the Trnovski gozd plateau in west Slovenia. Cave and Karst Science, (1994) , 21, 67-69.

Mihevc, A., 1996: The cave Brezstropa jama near Povir (in Slovene, English abstract). Naše jame, 38, 65 - 75, Ljubljana.

Mihevc, A., 1998-a: Brezstropa jama pri Povirju in denudirane jame v okolici Divače. Geografski obzornik, 45 (2), 12-17, Ljubljana.

\footnotetext{
${ }^{24}$ The titles of summaries are given to show English reades the contents of the original texts, which are considered in their entirety in this paper.
} 
Mihevc, A., 1998-b: Dolines, their morphology and origin. Case study: dolines from the Kras, West Slovenia (The Škocjan Karst). Fourth International Conference on Geomorphology, Suppl. Geogr. Fis. Dinam. Quat., III, T. 4 (1998), 69-74, Torino.

Mihevc, A., A. Kranjc, 1998: Classical Karst fieldtrip guide. Fourth International Conference on Geomorphology, Meeting M3, Lipica, august, 24-28, 1997, 1-53, Postojna.

Mihevc, A., N. Zupan Hajna 1996: Clastic Sediments from Dolines and Caves Found During the Construction of the Motorway near Divača, on the Classical Karst. Acta carsologica, 25, 169-191, Ljubljana.

Šebela S., A. Mihevc 1995: The problems of construction on karst - The examples from Slovenia. Karst Geohazards, Engineering and Environmental Problems in Karst Terrane, Proceedings of the Fifth Multidisciplinary Conference on Sinkholes and the Engineering and Environmental Impacts on Karst / Ed. Barry F. Beck, 475-479, Rotterdam / Brookfield.

Šušteršič, F., 1979: What is speleometry (in Slovene, English summary). Naše jame, 20, 21 -29, Ljubljana.

Šušteršič, F., 1982: Some considerations about the spatial organization of the karst terrains. (in Slovene, English summary). Geografski vestnik, 54, 19-28, Ljubljana.

Šušteršič, F., 1984: A monologue on spelogenesis (in Slovene, English summary). Naše jame, 26, 59 - 66, Ljubljana.

Šušteršič, F., 1991: On the objective of the spelological science (in Slovene, English summary). Naše jame, 33, 73 - 85, Ljubljana.

Šušteršič, F., 1994: Jama Kloka in začetje. Naše jame, 36, 9 - 30, Ljubljana.

Šušteršič, F., 1996-a: The pure karst model. Cave and karst science, 23 (1), 25 - 32, Ljubljana.

Šušteršič, F., 1996-b: Poljes and caves of Notranjska. Acta carsologica 25, 251 - 289, Ljubljana.

Šušteršič, F., 1998: Interaction between a cave system and the lowering karst surface; Case study: Laški Ravnik. Acta carsologica, 27, 2, 115 - 138, Ljubljana.

Šušteršič, F., M. Puc, 1970: The karst underground by the NE nook of the Planinsko polje (in Slovene, English abstract). Acta carsologica 5, 205 - 270, Ljubljana.

White, W.B., 1988: Geomorphology and hydrogeology of karst terrains. Oxford university press, 1 - 464, New York.

Williams, P. W., 1983: The role of the subcutaneous zone in karst hydrology. Journal of hydrology, 61, 45 - 67, Amsterdam.

\section{VERTIKALNA CONACIJA SPELEOGENETSKEGA PROSTORA}

\section{Povzetek}

Spoznanje, da "brezstrope jame" (A. Mihevc, 1996) niso samo zanimiva posebnost, ampak da samoumevno spadajo v inventar površja krasa, ni prineslo samo odkritja doslej neznanih - ali vsaj napačno interpretiranih oblik - ampak tudi omogoča, da vso zgodovino kraških votlin trdneje vpnemo v geospeleološki prostor/čas.

Čeprav daleč od sistematičnega pristopa, nosi klico bolj posplošenega gledanja P. Habičeva $(1976,19)$ misel, ko govori o jamah v zaledju Vrhniških izvirov: “... ugotovimo tri bolj poudarjena nadstropja. Najnjižje je danes aktivno, srednje, ki je najobsežnejše in pretežno suho ter najvišje, ki 
so ga podori razsekali na krajšse odseke." ${ }^{25}$ Iz konteksta je še razvidno, da je za najvišje nadstropje predvsem odločilna bližina površja. Šele A. Mihevc (o.c., 66) pa je jasno zapisal: “Čeprav jamski rov brez stropa nekako ni več jama. ... nam rov pokaže na drugi konec speleogeneze, na spemembo jame v površinsko kraško reliefno obliko ali celo popolno izginotje jame."

V tem članku želim pokazati, da lahko podzemske kraške pojave, ki jih denudacija "prinese" na kraško površje, opazujemo in preučujemo v dosti večji meri, kot smo domnevali doslej in da lahko z njihovo pomočjo izluščimo gotove zakonitosti o zgradbi jamskega spleta, ki nam pri tradicionalnem speleološkem pristopu ostanejo skrite ali težko preverljive.

Ne gede na to, da govorimo o pojavih znotraj kraškega površja oz. najbližje soseščine, je naša pozornost usmerjena izključno v kraške votline. Da bi bila raztrava jasna in dosledna, je nujno uvesti nekaj novih izrazov oz. definicij, ki pokrivajo že znane pojme z zelo bližnjih vej speleologije. Čeprav to do neke mere pomeni množenje sorodnih izrazov, se le tako izognemo dvoumju.

V prejšnjih svojih delih (F. Šušteršič, 1984, p. 65) sem kot kriterij za definicijo kraške votline postavil pogoj, da potekajo trajektorije vodnega toka, ki votlino oblikuje skozi obroč faznih meja, to je skozi diferencialni element spelogena (DES). V tem kontekstu je speleogenetski prostor (F. Šušteršič, 1991) definiran kot tisti predel v zemeljski skorji, kjer lahko (ali so že) nastanejo kraške votline. Podzemsko zakrasevanje je tako vzpostavljanje nizov DES-ov, zakraselo pdozemlje pa aktiviran speleogenetski prostor.

Speleogenetski prostor tradicionalno delimo v dve osnovni coni, prežeto (freatično) in neprežeto (vadozno, aeracijsko). Delitev je v osnovi hidrogeološka (pedološka), a se dobro sklada z dvema osnovnima tipoma kraških votlin, z "vodoravnimi" jamami in brezni. S stališča speleogeneze je pomembna razlika, da so pri enosmernem razvoju inicialne strukture votlin v prežeti coni lahko samo geološke, v neprežeti pa geološke ali (podedovane) speleološke.

Zaradi denudacije in zniževanj gladine podtalnice, se zdi, kot da se posamezna voltlina prežete cone s časom pomika v neprežeto in končno dospe na površje krasa. Logika kraške denudacije je navpična (F. Šušteršič, 1996-a); zato ni premeščanja mase znotraj površja, marveč korozija načenja kamnino do določene globine (I. Gams, 1997) in postopoma razgrajuje njene površju najbližje predele. Seveda velja zadnja ugotovitev tudi za pojave znotraj napadene kamnine, to je kraške votlin, "podedovane" iz spodnjih dveh con.

Najvišji predel zakrasele kraške gmote hidrološko šteje seveda v neprežeto cono - največkrat ga imenujemo epikraška cona - vendar je njegova vloga s stališča speleogeneze diametralno različna nižjim predelom. Kraške votline tu ne nastajajo, ampak ginejo. Zato ga imenujmo speleotanatska cona $^{26}$. Znotraj speleotanatske cone je napadena vsa kamnina, na vseh možnih površinah, ne le stene kanalov. Končni rezultat je popolen razkroj tako kamnine kot votlin v njej.

Ugotovitev, da obstoja v spelogenetskem prostoru domena, kjer jame izginjajo, ne pa nastajajo, je tako upravičena. Ni verjetno, da bi Habič (o.c.) s svojimi razmišljanji prišel tako daleč. Je pa terminologija, ki jo je uvedel zelo uporabna, še posebej ker je pregledna in ob enem popolnoma nevtralna. Ne glede na predzgodovino znanstvene misli lahko njegove ugotovitve posplošimo in definiramo znotraj speleogenetskega prostora tri nadstropja:

\footnotetext{
${ }^{25}$ Prevod France $\check{\text { Šušteršič. }}$

${ }^{26} \mathrm{Gr} .: \vartheta \alpha v \alpha \tau 0 \sigma=s m r t$.
} 
Tabela 1.1:

\begin{tabular}{|c|c|c|c|}
\hline $\begin{array}{c}\text { temeljni } \\
\text { speleološki izraz }\end{array}$ & $\begin{array}{c}\text { Habičeva } \\
\text { terminologija }\end{array}$ & $\begin{array}{l}\text { speleološki } \\
\text { proces }\end{array}$ & $\begin{array}{c}\text { splošno } \\
\text { dogajanje }\end{array}$ \\
\hline $\begin{array}{c}\text { domena } \\
\text { razpadanja }\end{array}$ & najvišje nadstropje & DESi razpadajo & popolen razkroj \\
\hline $\begin{array}{c}\text { domena } \\
\text { oblikovanja }\end{array}$ & $\begin{array}{l}\text { srednje nadstropje } \\
\text { najnižje nadstropje }\end{array}$ & $\begin{array}{c}\text { nastajanje navpično } \\
\text { usmerjenih DES-ov } \\
\text { nastajanje "vodoravno" } \\
\text { usmerjenih DES-ov }\end{array}$ & $\begin{array}{c}\text { nastajanje kaminov } \\
\text { (brezen) } \\
\text { nastajanje "vodoravnih" } \\
\text { jam }\end{array}$ \\
\hline
\end{tabular}

Izraz "domena oblikovanja” velja samo s stališča kraških votlin, ki so negativna gmota. S stališča pozitivne mase seveda tudi tu vlada razpadanje, ki pa ni totalno, temveč zakonito umeščeno v prostor.

Če skladno z navedeno logiko uredimo še nekaj znanih speleoloških dejstev, lahko gornjo tabelo razvijemo v:

Tabela 1.2:

\begin{tabular}{|c|c|c|c|c|}
\hline $\begin{array}{c}\text { Habičeva } \\
\text { terminologija }\end{array}$ & $\begin{array}{c}\text { Hidrološka } \\
\text { funkcija }\end{array}$ & $\begin{array}{c}\text { Adaptacija } \\
\text { geoloških struktur }\end{array}$ & $\begin{array}{c}\text { Značilnosti } \\
\text { procesov }\end{array}$ & $\begin{array}{c}\text { Prevladujoče } \\
\text { dogajanje }\end{array}$ \\
\hline $\begin{array}{c}\text { najvišje } \\
\text { nadstropje }\end{array}$ & epikras & $\begin{array}{c}\text { totalna } \\
\text { aktivacija } \\
\text { vseh struktur }\end{array}$ & bioaktivnost & $\begin{array}{c}\text { popolen razkroj } \\
\text { kamnine }\end{array}$ \\
\hline $\begin{array}{c}\text { srednje } \\
\text { nadstropje }\end{array}$ & neprežeta cona & navpični preboji & $\begin{array}{c}\text { ni povratnega } \\
\text { učinka (navzgor) }\end{array}$ & $\begin{array}{c}\text { nastajanje kamnov } \\
\text { in brezen }\end{array}$ \\
\hline $\begin{array}{c}\text { najnižje } \\
\text { nadstropje }\end{array}$ & prežeta cona & $\begin{array}{c}\text { selektivna } \\
\text { aktivacija } \\
\text { geoloških struktur }\end{array}$ & $\begin{array}{c}\text { sistem veznih } \\
\text { posod }\end{array}$ & $\begin{array}{c}\text { nastajanje } \\
\text { oblezičnih } \\
\text { kanalov in } \\
\text { freatičnih skokov }\end{array}$ \\
\hline
\end{tabular}

Če bi želeli biti popolnoma dosledni, bi morali pod prežeto cono definirati še cono, ki še ni aktivirana. Ker je ta podrobnost popolnoma izven naše razprave, se z njo ne bomo več ukvarjali.

Če postavimo prejšnje ugotovitve v širši geospeleološki okvir in upoštevamo podrobnosti, ki smo jih prej preskočili, lahko sestavimo naslednjo speleologenetsko shemo: 
Tabela 2:

\begin{tabular}{|c|c|c|c|}
\hline \multirow{2}{*}{$\begin{array}{c}\text { Speleološki } \\
\text { proces }\end{array}$} & \multirow{2}{*}{\multicolumn{2}{|c|}{$\begin{array}{c}\text { Procesi v speleogenetskem } \\
\text { prostoru } \\
(\text { razvoj DES-ov) }\end{array}$}} & Proces v kamnini \\
\hline & & & \multirow{2}{*}{ DIAGNEZA } \\
\hline \multirow[t]{4}{*}{ 1. Speleogeneza } & 1.1 & Začetje & \\
\hline & 1.2 & Snovanje & \multirow{7}{*}{ NADOMEŠČANJE } \\
\hline & 1.3 & Večanje & \\
\hline & 1.4 & Stagnacija & \\
\hline \multirow[t]{3}{*}{ 2. Transformacija } & 2.1 & Podor & \\
\hline & 2.2 & Nastajanje stropnih kaminov & \\
\hline & 2.3 & Zapolnjevanje & \\
\hline \multirow[t]{3}{*}{ 3. Razpad } & 3.1 & Razpad stropa & \\
\hline & 3.2 & Razpad sten & \\
\hline & 3.3 & Talni procesi v polnilu & PEDOGENEZA \\
\hline
\end{tabular}

Preperevanje kamnine ne vodi samo k uničenju kraških votlin, temveč učinkuje na vse izpostavljene živoskalne površine. Nastane niz oblik, ki enako odražajo izhodiščno strukturo, kot okoliščine preprevanja. Poudariti pa je treba, da tako nastale negativne oblike praviloma ne zadoščajo kriteriju "trajektorija skozi DES-e".

Prostorsko se speleotanatska cona približno krije z epikraško cono oz. cono subkutanega zakrasevanja. Podrobna analiza razumevanja obeh con v literaturi je pokazala, da je vsebinska sorodnost večja z epikraško cono, popolne skladnosti pa že glede na izhodišče za definicijo ne more biti.

Vprašanje spodnje meje speleotanatske cone tako ostaja odprto. V svojih zadnjih delih se I. Gams (1997, 1998) večkrat sklicuje na korozijsko fronto, za katero se zdi, da je vsebinsko blizu. Podpisani izrazu žal nisem utegnil slediti do korenin in preveriti začetne definicije. Odločujoči kriteriji se zdijo nastajanje žepov, penetracija zemljine in povečana bioaktivnost. Kaj pa vodi do nastajanja žepov še vedno ni popolnoma pojasnjeno. Običajna razlaga je, da se razpoke odprejo zaradi razbremenitve ali tektonskega dviga, ne gre pa pozabiti tudi na pleistocensko zmrzovanje, oddajanje vode in ponovno nabrekanje glinenih mineralov ipd. 